\title{
Increase of binucleated cells in the oral mucosa: a study on the use of psychotropics by students of a Brazilian institution
}

\author{
(1D) Luiza Barbosa de Oliveira" ${ }^{1 \#}$ \\ Joyce Aparecida Rezende Parreiras"\# \\ (iD) Elza Conceição de Oliveira Sebastião ${ }^{2 \#}$ \\ (iD) Glenda Nicioli da Silva,4\#
}

\begin{abstract}
1. Medical School, University Campus Morro do Cruzeiro, Federal University of Ouro Preto, Ouro Preto, MG, Brasil. 2. Clinical Pharmacy Laboratory, Pharmacy Department, Pharmacy School, University Campus Morro do Cruzeiro, Federal University of Ouro Preto, Ouro Preto, MG, Brasil

3. Postgraduate Program on Pharmaceutical Sciences (CIPHARMA), Pharmacy School, University Campus Morro do Cruzeiro, Federal University of Ouro Preto, Ouro Preto, MG, Brasil. 4. Clinical Analysis Department, Pharmacy School, University Campus Morro do Cruzeiro, Federal University of Ouro Preto, Ouro Preto, MG, Brasil. \# Equal contribuitions
\end{abstract}

http://dx.doi.org/10.1590/1806-9282.65.6.870

\begin{abstract}
SUMMARY
This study aimed to assess the prevalence of medical and nonmedical use of psychiatric medication among undergraduate students of health sciences from a public university in Brasil. Another objective was to determine the frequency of nuclear morphological abnormalities in the buccal mucosa of students using psychiatric drugs. A cross-sectional study based on a Web survey was carried out with 375 health sciences undergraduate students from schools of Pharmacy, Physical Education, Nutrition, and Medicine. Additionally, spontaneous genetic damages in exfoliated cells of the buccal mucosa of 41 individuals by counting micronucleus (MN) and binucleated (BN) cells frequencies were evaluated. The results showed 76 (20.3\%) of students reported the use of psychotropic drugs after enrolling in university. The majority of these students were from Pharmacy and Medicine programs, females, aged between 18-25 years old, nonsmokers, alcohol addicts, and with a family history of mental illness. In addition, Medical students, individuals with high-income, who live alone and are in the last period of the program are more likely to use psychotropic drugs. Moreover, exposure to psychiatric medication was able to increase the number of binucleated cells. These results provide evidence that the use of psychoactive drugs is increased in the academic context and may be related to the failure of the cell cycle.
\end{abstract}

KEYWORDS: Chromosome Aberrations, Drugs Utilization, Psychotropic Drugs, Students.

\section{INTRODUCTION}

Several studies have reported that undergraduate students have psychological morbidities worldwide $^{1-8}$. Approximately $12-18 \%$ of students on college campuses in the United States of America have a diagnosable mental illness'. Anxiety disorders are the most prevalent psychiatric problems among American college students, with approximately $15.9 \%$ of students suffering from an anxiety disorder, such as panic disorder, social anxiety disorder, specific phobia, or generalized anxiety disorder ${ }^{2}$. Another common mental health problem among American college students is major depression, with a prevalence rate of $9 \%^{3}$. A cross-sectional study in Colombia showed that the prevalence of psychotropic drug users was $18.3 \%$ for nursing students and $16.5 \%$ for medical students and that antidepressants were the

DATE OF SUBMISSION: 31-Mar-2019

DATE OF ACCEPTANCE: 19-Apr-2019

CORRESPONDING AUTHOR: Glenda Nicioli da Silva

Clinical Analysis Department, Pharmacy School, University Campus Morro do Cruzeiro, Federal

University of Ouro Preto, CEP: 35400-000, Ouro Preto, MG, Brasil

E-mail: nicioli@ufop.edu.br 
most consumed psychotropic drug (12.9\%) ${ }^{4}$. In Brasil, the prevalence of common mental disorders among medical students at the Federal University of Bahia and at the Federal University of Espírito Santo was $29.6 \%$ and $37.1 \%$, respectively ${ }^{5,6}$. A study performed at a public nursing school in the state of São Paulo, Brasil, indicated that $16 \%$ of 308 students were using anxiolytics when the study was performed or had already used anxiolytics at some time in their lives ${ }^{7}$. Another study was carried out in a public medical school in the state of Sao Paulo, Brasil. Of the 289 students interviewed, $11.4 \%$ were using or had already used antidepressants, with fluoxetine being the most prescribed ${ }^{8}$.

These prevalence rates may be due to the fact that attending college is a challenging time for many students, as they have many performance barriers and adult-like responsibilities, such as maintaining concentration, making decisions, meeting deadlines under pressure, making public presentations, and maintaining a good attendance record. Health science students have some other stressful factors that include excessive study load, extensive curriculum, lack of leisure time, and contact with death and diseases $^{9}$. These situations may lead to mental disorders and high consumption of psychotropic drugs.

Furthermore, college students often engage in the non-medical use of prescription medications, namely taking prescription medications without having a prescription. Approximately one in every five individuals reported nonmedical use of at least one class of prescription medication in their lifetime in an American cross-sectional web survey conducted among college students from 2003 to $2013^{10}$. Another concern is the misuse of prescription medications by taking more than the prescribed dose. Stimulants such as amphetamine/methylphenidates are one of the most commonly misused medications among college students, with $5-35 \%$ of college students having misused stimulants. The most commonly reported reasons for the use of stimulants that were not prescribed include studying, staying awake, and improved alertness ${ }^{11}$.

Considering the range of health and socio-economic problems associated with psychological morbidities, various generations of drugs, such as antidepressants, anxiolytics, and stimulants, have been designed. Although it is well known that these drugs can cause adverse reactions, such as xerostomia, ulcers, and hyperplasia, their effect on genetic ma- terial deserves further investigation ${ }^{12,13}$. Genotoxicity can be observed by the increase in the frequency of micronuclei (MN) in exfoliated epithelial cells ${ }^{14}$. Chromosome fragments or whole chromosomes that are not included in the main cores during nuclear division produce MNs that reflect chromosomal damage. Other nuclear alterations can be observed after exposure to a genotoxic agent, such as nuclear buds, cytoplasmic bridges, pyknosis, karyorrhexis, increased numbers of binucleated cells, and karyolysis. The increase in the frequency of these alterations is not related to malignancy; however, it is a viable index to assess the genotoxicity of exposure to various carcinogens ${ }^{15}$.

The objective of this study was to assess the prevalence of the medical and nonmedical use of psychiatric medication (opioids, stimulants, sleeping pills, and sedative/anxiety medications) among university students of health sciences (medicine, nutrition, pharmacology, and physical education) at a public university in Brasil. It also aimed to evaluate the relationship between the students' basic socio-demographic variables and their psychological health. The pharmacological classification, the most common drugs used by students, and the person who motivated the consumption of psychotropic drugs were also investigated. The frequency of micronuclei (MN) and other nuclear abnormalities in the buccal mucosa of undergraduate students using or not using psychiatric medication was also determined.

\section{METHODS}

\section{Epidemiological study}

A cross-sectional study was carried out from May to June of 2017. A total of 1560 health sciences undergraduate students, including those attending programs of Pharmacy (461), Medicine (476), Physical education (341) and Nutrition (282), were enrolled in 2017 at the Federal University of Ouro Preto (UFOP). The sample size was calculated using the Program Stat-Calc and the following data: expected frequency of respondents of $50 \%$, alpha value of $5 \%$ and power of study of $80 \%$. Thus, the minimum appropriate sample size was 373 undergraduate students. The total number of respondents was 375 . The study received approval from the Brazilian Human Research Ethics Committee of Centro Universitário Newton Paiva, under protocol n. 2.016.320.

The students received a pre-notification letter de- 
scribing the study and inviting them to self-administer a Web survey by using a URL address. Informed consent was obtained online from each participant. Two reminder emails were sent to non-respondents.

The students were asked to complete a self-administered questionnaire which was developed by the authors and adapted from a household survey concerning the use of psychotropic drugs in Brasil ${ }^{16}$. The questionnaire requested information on identification (age, gender, semester and marital status), life habits (cigarette smoking and alcohol use), family history of mental illness or disease related to the oral cavity, and socioeconomic conditions (health insurance, monthly income, whether the student lives on their own or who they live with). The use of psychiatric medication was assessed with the following items: frequency, motive, time of use, difficulty of acquisition, tolerance, and adverse reactions.

With the help of Microsoft Office Excel 2010, the collected data were tabulated and statistically processed using the software EPI Info ${ }^{\mathrm{TM}} 7$ (Version 7.1.4). The students were compared for demographic and socioeconomic variables and the use of psychiatric medication using the chi-square test. A $p$-value $<0.05$ was used to indicate a statistically significant difference. If there was a significant difference between variables, the particular exposure was determined as a risk factor using the odds ratio.

\section{Micronucleus Assay}

To evaluate the genotoxicity of psychiatric medication, the micronucleus test was performed. Taking into consideration the effects of age, gender, tobacco and alcohol consumption on the induction of micronucleus, the samples comprised consisted of students older than 18 years and younger than 30, nonsmokers with no history of smoking, and alcohol consumption of less than 12 "standard drinks" per fortnight. Amounts are based on a "standard drink", which is defined as 1 glass of beer, 1 glass of wine, or $1 / 2$ a dose of distilled drink. The National Institute on Alcohol Abuse and Alcoholism (NIAAA) in the United States has estimated consumption amounts of alcohol that increase health risks as more than 7 standard drinks per week for women and more than 14 standard drinks per week, on average, for men ${ }^{17}$. Taking into account that DNA damage occurs before the manifestation of symptoms, we consider the damaging values of alcohol consumption, regardless of sex, to be lower than those recommended by NIAAA.
Thus, from the 375 students that answered the web survey, 41 individuals presented the inclusion criteria and voluntary participation in the second part of this research, being 19 (14 women and 5 men) students exposed to psychotropic drugs and 22 (15 women and 7 men) non-exposed controls.

Exfoliated cells of the oral mucosa were collected according to Thomas et al. ${ }^{14}$. Briefly, buccal cells were fixed in Saccomanno's solution (50\% (vol/vol) ethanol and $2 \%(\mathrm{vol} / \mathrm{vol})$ polyethylene glycol). The cells were centrifuged for $10 \mathrm{~min}$ at $1500 \mathrm{rpm}$ at room temperature. The supernatant was aspirated off, leaving approximately $1 \mathrm{ml}$ of cell suspension, to which $5 \mathrm{ml}$ of buccal cell buffer, containing tris-hydrochloric acid, ethylenediamine tetraacetic acid, and sodium chloride, were then added. These two steps were repeated twice more. The cells were fixed with $4 \mathrm{ml}$ of ethanol: glacial acetic acid (3:1) for 10 min before preparing the slides. The slides were fixed for $1 \mathrm{~min}$ in Coplin jars containing $50 \%(\mathrm{vol} / \mathrm{vol})$ and $20 \%(\mathrm{vol} / \mathrm{vol})$ ethanol. The slides were washed and then placed in $5 \mathrm{M}$ $\mathrm{HCl}$ for $30 \mathrm{~min}$. The sample was stained using the reactive Schiff for $60 \mathrm{~min}$ in the dark at room temperature, counter-stained using Fast Green for 20-30 sec and rinsed in Milli-Q water. The cytological analysis was conducted under an optical microscope at 400x. Slides were coded for blind scoring and analyzed by two independent slide readers (LBO and JARP). In total, over 2000 cells were analyzed for each individual. Nuclear alterations (micronucleus, pyknosis, karyorrhexis, condensed chromatin, karyolysis, and the number of binucleated cells) were observed. The scoring criteria for the various distinct cell types and nuclear abnormalities were based on those described by Thomas et al. ${ }^{14}$.

The frequency of micronuclei and other nuclear alterations in the buccal mucosa cells of students were computed. To compare differences between the case and control groups, the Mann-Whitney test was performed using the GraphPad Prism Software. $P$ value $<0.05$ was used to indicate a statistically significant difference.

\section{RESULTS}

\section{Pharmacoepidemiological study}

The number of respondents to the electronic questionnaire was 375 individuals. The socioeconomic data of the participants are shown in Table 1. The respondents to the questionnaire were predominantly fe- 
TABLE 1: FREQUENCY AND PERCENTAGE OF SOCIO-DEMOGRAPHIC CHARACTERISTICS OF STUDY PARTICIPANTS

\begin{tabular}{|c|c|c|}
\hline Variables & $F(n=375)$ & $\%$ \\
\hline \multicolumn{3}{|l|}{ Undergraduate course } \\
\hline Physical Education Bachelor & 40 & 10.6 \\
\hline Physical Education Graduation & 17 & 4.6 \\
\hline Pharmacy & 143 & 38.2 \\
\hline Medicine & 100 & 26.6 \\
\hline Nutrition & 75 & 20.0 \\
\hline \multicolumn{3}{|l|}{ Gender } \\
\hline Female & 290 & 77.3 \\
\hline $\begin{array}{l}\text { Male } \\
\text { Unfilled answer }\end{array}$ & $\begin{array}{l}82 \\
3 \\
\end{array}$ & $\begin{array}{l}21.8 \\
0.9 \\
\end{array}$ \\
\hline \multicolumn{3}{|l|}{ Age group } \\
\hline$<18$ years & 7 & 1.9 \\
\hline $18-25$ & 254 & 67.7 \\
\hline $25-30$ & 96 & 25.7 \\
\hline $\begin{array}{l}\text { > } 30 \text { years } \\
\text { Unfilled answer }\end{array}$ & $\begin{array}{l}17 \\
1 \\
\end{array}$ & $\begin{array}{l}4.4 \\
0.3 \\
\end{array}$ \\
\hline \multicolumn{3}{|l|}{ Marital status } \\
\hline Stable union & 11 & 2.9 \\
\hline Married & 18 & 4.8 \\
\hline Single & 338 & 90.1 \\
\hline Divorced & 5 & 1.3 \\
\hline $\begin{array}{l}\text { Widowed } \\
\text { Unfilled answer }\end{array}$ & $\begin{array}{l}1 \\
2 \\
\end{array}$ & $\begin{array}{l}0.3 \\
0.6\end{array}$ \\
\hline \multicolumn{3}{|l|}{ Religion } \\
\hline Agnostic & 19 & 5.1 \\
\hline Atheist & 12 & 3.2 \\
\hline Buddhist & 3 & 0.9 \\
\hline Catholic & 180 & 48.0 \\
\hline Christian & 20 & 5.3 \\
\hline Spiritism & 36 & 9.6 \\
\hline Evangelical & 10 & 2.6 \\
\hline Gnosticism & 1 & 0.3 \\
\hline Jewish & 1 & 0.3 \\
\hline
\end{tabular}

\begin{tabular}{|c|c|c|}
\hline Variables & $F(n=375)$ & $\%$ \\
\hline Protestant & 4 & 1.0 \\
\hline Umbandista & 4 & 1.0 \\
\hline $\begin{array}{l}\text { No religion } \\
\text { Unfilled answer }\end{array}$ & $\begin{array}{l}45 \\
40\end{array}$ & $\begin{array}{l}12.0 \\
10.7 \\
\end{array}$ \\
\hline \multicolumn{3}{|l|}{ Income } \\
\hline$<1$ wage & 30 & 8.0 \\
\hline $1-5$ wages & 158 & 42.1 \\
\hline 5-10 wages & 55 & 14.6 \\
\hline $\begin{array}{l}>10 \text { wages } \\
\text { Unfilled answer }\end{array}$ & $\begin{array}{l}24 \\
108 \\
\end{array}$ & $\begin{array}{l}6.4 \\
28.9\end{array}$ \\
\hline \multicolumn{3}{|l|}{ Addiction to tobacco } \\
\hline Smoker & 32 & 8.5 \\
\hline Were you ever a smoker? & 36 & 9.6 \\
\hline $\begin{array}{l}\text { Not addicted } \\
\text { Unfilled answer }\end{array}$ & $\begin{array}{l}306 \\
1 \\
\end{array}$ & $\begin{array}{l}81.6 \\
0.3\end{array}$ \\
\hline \multicolumn{3}{|l|}{ Alcohol consumption } \\
\hline Presence & 272 & 72.5 \\
\hline $\begin{array}{l}\text { Absence } \\
\text { Unfilled answer }\end{array}$ & $\begin{array}{l}102 \\
1\end{array}$ & $\begin{array}{l}27.2 \\
0.3\end{array}$ \\
\hline \multicolumn{3}{|c|}{ Family history of mental illness } \\
\hline Presence & 223 & 59.4 \\
\hline $\begin{array}{l}\text { Absence } \\
\text { Unfilled answer }\end{array}$ & $\begin{array}{l}151 \\
1 \\
\end{array}$ & $\begin{array}{l}40.3 \\
0.3 \\
\end{array}$ \\
\hline \multicolumn{3}{|l|}{$\begin{array}{l}\text { Family history of buccal } \\
\text { mucosa problems }\end{array}$} \\
\hline Presence & 41 & 10.9 \\
\hline $\begin{array}{l}\text { Absence } \\
\text { Unfilled answer }\end{array}$ & $\begin{array}{l}333 \\
1 \\
\end{array}$ & $\begin{array}{l}88.8 \\
0.3\end{array}$ \\
\hline \multicolumn{3}{|l|}{ Living arrangement } \\
\hline Friends & 176 & 46.9 \\
\hline Spouse & 28 & 7.4 \\
\hline Parents & 127 & 33.9 \\
\hline $\begin{array}{l}\text { Alone } \\
\text { Unfilled } \\
\text { answer }\end{array}$ & $\begin{array}{l}43 \\
1\end{array}$ & $\begin{array}{l}11.5 \\
0.3\end{array}$ \\
\hline
\end{tabular}

Ouro Preto Federal University. Ouro Preto. MG. 2017. *Brazilian minimum wage at the time of the study was R\$954.

male $(\mathrm{n}=290,77.3 \%)$, unmarried $(\mathrm{n}=338,90.1 \%)$ and aged between 18 and 25 years $(\mathrm{n}=254,67.7 \%)$.

Of the 375 students, 76 (20.3\%) reported they used psychotropic drugs after admission to the University. Table 2 shows that the use of psychotropic drugs is higher among university students in Medicine and Pharmacy programs, females, age between 18 and 25 years, single, catholic, with income of 1-10 minimum wages (according to the reference standard for income of the Brazilian Institute of Geography and Statistics of 2018, when the minimum wage was 954 Brazilian Reals), non-smokers, alcoholics, living alone, and with a family history of mental illness. The statistical associations can be observed in Table 3. Observing the odds ratio, individuals in medical school are 7.943 times more likely to use psychotro- pic drugs than those in other programs, followed by individuals in pharmacy school (4.912 times). University students with an income between 5 and 10 minimum wages are 1.681 times more likely to use psychotropic drugs. The study also indicated that individuals living alone (2.109 times) and with a family history of mental illness (3.768 times) are more likely to use psychotropic drugs. A linear analysis for trends in proportions was performed considering the program period of all students and a significant statistical association was found between the academic semester regardless of the course and the use of psychotropic drugs $\left(X^{2}=4.570, p=0.0289\right)$; students in the last semester has a 15.750 times higher chance of using psychoactive drugs, followed by those in the third semester (3.370 times). 
TABLE 2: FREQUENCY AND PERCENTAGE OF SOCIO-DEMOGRAPHIC CHARACTERISTICS OF STUDY PARTICIPANTS WHO REPORTED THE USE OF PSYCHOTROPIC DRUGS AFTER ADMISSION TO THE UNIVERSITY

\begin{tabular}{l|l|l} 
Variables & & \\
\hline Undergraduate course & 2 & 2.6 \\
\hline Physical Education Bachelor & 1 & 1.3 \\
\hline Physical Education Graduation & 30 & 39.5 \\
\hline Pharmacy & 30 & 39.5 \\
\hline Medicine & 13 & 17.1 \\
\hline Nutrition & & \\
\hline Gender & 56 & 73.7 \\
\hline Female & 20 & 26.3 \\
\hline Male & & \\
\hline Age group & 0 & 0.0 \\
\hline$<18$ years & 47 & 61.8 \\
\hline 18-25 & 23 & 30.3 \\
\hline 25-30 & 6 & 7.9 \\
\hline$>30$ years & & \\
\hline Marital status & 1 & 1.3 \\
\hline Stable union & 6 & 7.9 \\
\hline Married & 69 & 90.8 \\
\hline Single & 0 & 0.0 \\
\hline Divorced & 0 & 0.0 \\
\hline Widowed & & \\
\hline Religion & 5 & 6.6 \\
\hline Agnostic & 2 & 2.6 \\
\hline Atheist & 0 & 0.0 \\
\hline Buddhist & 33 & 43.4 \\
\hline Catholic & 2 & 2.7 \\
\hline Christian & 9 & 11.8 \\
\hline Spiritism & 3 & 4.0 \\
\hline Evangelical & 0 & 0.0 \\
\hline Gnosticism & 0 & 0.0 \\
\hline ewish & & \\
\hline & & \\
\hline & & \\
\hline & & \\
\hline
\end{tabular}

\begin{tabular}{l|l|l} 
Variables & \multicolumn{1}{l}{$\mathrm{F}(\mathrm{n}=76)$} & $\%$ \\
\hline Protestant & 0 & 0.0 \\
\hline Umbandista & 0 & 0.0 \\
\hline $\begin{array}{l}\text { No religion } \\
\text { Unfilled answer }\end{array}$ & 14 & 18.4 \\
\hline Income & 8 & 10.5 \\
\hline$<1$ wage & & \\
\hline $1-5$ wages & 7 & 9.2 \\
\hline 5-10 wages & 21 & 27.6 \\
\hline >10 wages & 22 & 29.0 \\
\hline Unfilled answer & 9 & 11.9 \\
\hline Addiction to tobacco & 17 & 22.3 \\
\hline Smoker & & \\
\hline Were you ever a smoker? & 8 & 10.5 \\
\hline Not addicted & 8 & 10.5 \\
\hline Alcohol consumption & & \\
\hline Presence & 60 & 79.0 \\
\hline Absence & & \\
\hline Family history of mental illness & & 75.0 \\
\hline Presence & 19 & 25.0 \\
\hline Absence & 62 & 81.6 \\
\hline Family history of buccal mucosa \\
problems & 14 & 18.4 \\
\hline Presence & & \\
\hline Absence & 10 & 13.2 \\
\hline Living arrangement & 66 & 86.8 \\
\hline Friends & 30 & 39.5 \\
\hline Spouse & 8 & 10.5 \\
\hline Parents & 25 & 32.9 \\
\hline Alone & 13 & 17.1 \\
\hline & & \\
\hline
\end{tabular}

Ouro Preto Federal University, Ouro Preto, MG, 2017.

Of the 76 students who used psychotropic drugs, with respect to the degree of difficulty of acquisition, 29 (38.1\%) reported that it was easy to obtain the drugs, 27 (35.15\%) as reasonable, and $7(9.2 \%)$ as difficult. 13 individuals (17.2\%) did not answer this question. The main difficulties were related to obtaining the prescription and price, 24 (31.5\%) and 16 (21.1\%), respectively. $13(17.1 \%)$ individuals did not report difficulties, and 23 (30.3\%) subjects did not answer this question. In addition, 38 students (50.0\%) reported not having used more psychiatric medication than they would like, and $52(68.4 \%)$ reported that they did not develop medication tolerance, so there was no need to increase the dosage in order to obtain the desired effect. As for personal problems resulting from the use of psychotropics, 31 students (40.7\%) listed loss of appetite, loss of concentration, insomnia, drowsiness, and decreased libido in in- creasing order of prevalence. In addition, 15 (19.7\%) of the university students reported decreased school performance. Furthermore, 17 (22.3\%) individuals reported wanting to stop taking psychiatric medications, but they were afraid of the unpleasant side effects and worsening of symptoms. In addition, 27 (35.5\%) mentioned that they had sought specialized help to stop the use.

The 76 students who reported using psychopharmaceuticals together encompassed a use of a total of 140. Of these, 106 were classified according to the Anatomical Therapeutic Chemical (ATC); the most commonly used therapeutic class was antidepressants, NO6A, with emphasis on Fluoxetine $(n=19)$ (Figure 1). Others ATC classifications reported by the participants are described in Table 4. In addition, 36 people were using only one psychotropic drug, 36 individuals used 2 or 3 , and 4 used 4 or 5 psychotropic drugs. 
TABLE 3: ASSOCIATION BETWEEN THE USE OF PSYCHOACTIVE DRUGS AND SOCIODEMOGRAPHIC VARIABLES OF THE PARTICIPANTS OF THE STUDY WHO REPORTED THE USE OF PSYCHOTROPIC DRUGS AFTER ADMISSION TO THE UNIVERSITY

\begin{tabular}{|c|c|c|c|}
\hline$(\mathrm{N}=76)$ & OR & $\mathrm{X} 2$ & $P$ \\
\hline \multicolumn{4}{|l|}{ Variables } \\
\hline Undergraduate course & & 4.617 & 0.0316 \\
\hline Physical Education Bachelor & 1 & & \\
\hline Physical Education Graduation & 1.156 & & \\
\hline Pharmacy & 4.912 & & \\
\hline Medicine & 7.943 & & \\
\hline Nutrition & 3.943 & & \\
\hline Income* & & 12.073 & 0.0005 \\
\hline$<1$ wage & 1 & & \\
\hline $1-5$ wages & 0.504 & & \\
\hline 5-10 wages & 1.681 & & \\
\hline$>10$ wages & 1.971 & & \\
\hline Living arrangement & & 4.720 & 0.0298 \\
\hline Friends & 1 & & \\
\hline Spouse & 1.947 & & \\
\hline Parents & 1.193 & & \\
\hline Private accommodation & 2.109 & & \\
\hline $\begin{array}{l}\text { Positive family history of men- } \\
\text { tal illness }\end{array}$ & 3.768 & 17.968 & 5.4388 \\
\hline
\end{tabular}

\section{tal illness}

Ouro Preto Federal University, Ouro Preto, MG, 2017. *Brazilian minimum wage at the time of the study was R\$954.

TABLE 4: CLASSIFICATION OF PSYCHOTROPIC DRUGS USED BY STUDENTS ACCORDING TO THE ANATOMICAL THERAPEUTIC CHEMICAL CODE (ATC)

\begin{tabular}{l|l|l} 
ATC & $\begin{array}{l}\text { Number } \\
\text { of drugs } \\
(n=106)\end{array}$ & \multicolumn{2}{l}{ Classification } \\
\hline A08A & 2 & $\begin{array}{l}\text { Antiobesity preparations excluding } \\
\text { diet products }\end{array}$ \\
\hline N02A & 1 & Analgesics \\
\hline N03A & 5 & Antiepileptic \\
\hline N05A & 3 & Antipsychotics \\
\hline N05B & 12 & Anxiolytics \\
\hline N05C & 3 & Hypnotics and sedatives \\
\hline N06A & 66 & Antidepressants \\
\hline N06B & 10 & $\begin{array}{l}\text { Psychostimulants, agents used for } \\
\text { attention deficit hyperactivity disor- } \\
\text { der and nootropics }\end{array}$ \\
\hline N07B & 4 & Drugs used in addictive disorders \\
\hline
\end{tabular}

\section{Micronucleus Assay}

In the present study, frequencies of micronuclei and nuclear abnormalities such as nuclear bud, condensed chromatin, pyknosis, karyorrhexis, karyolysis, and nucleoplasmic bridge had no significant difference $(p>0.05)$ between the case and control groups. However, there was a statistically significant increase in binucleated cell number in the group exposed to psychotropic drugs (Table 5).
TABLE 5: MEAN NUMBER OF FREQUENCY OF MICRONUCLEI AND OTHER NUCLEAR ALTERATIONS IN STUDENTS EXPOSED TO PSYCHIATRIC MEDICATION AND NON-EXPOSED CONTROLS.

\begin{tabular}{|c|c|c|c|}
\hline $\begin{array}{l}\text { Nuclear alter- } \\
\text { ations }\end{array}$ & $\begin{array}{l}\text { Exposed stu- } \\
\text { dents }(n=19)\end{array}$ & $\begin{array}{l}\text { Non-exposed } \\
\text { students }(n=22)\end{array}$ & P-value \\
\hline Micronuclei & $1.447(0.072 \%)$ & $1.659(0.083 \%)$ & $p>0.05$ \\
\hline Nuclear buds & $1.079(0.054 \%)$ & $1.000(0.050 \%)$ & $p>0.05$ \\
\hline $\begin{array}{l}\text { Nucleoplasmic } \\
\text { bridges }\end{array}$ & $0.316(0.018 \%)$ & $0.500(0.025 \%)$ & $p>0.05$ \\
\hline $\begin{array}{l}\text { Condensed } \\
\text { chromatin }\end{array}$ & $0.079(0.004 \%)$ & $0.091(0.005 \%)$ & $p>0.05$ \\
\hline Karyorrhexis & $2.053(0.103 \%)$ & $2.159(0.108 \%)$ & $p>0.05$ \\
\hline Karyolysis & 21.605 (1.080\%) & $20.000(1.000 \%)$ & $p>0.05$ \\
\hline Pyknosis & $0.421(0.021 \%)$ & $0.341(0.017 \%)$ & $p>0.05$ \\
\hline $\begin{array}{l}\text { Binucleated } \\
\text { cells * }\end{array}$ & $8.184(0.409 \%)$ & $5.682(0.284 \%)$ & $p<0.05$ \\
\hline
\end{tabular}

FIGURE 1 - FREQUENCY OF 10 PSYCHOTROPIC DRUGS MOST USED BY STUDENTS AT THE FEDERAL UNIVERSITY OF OURO PRETO. MG. 2017.

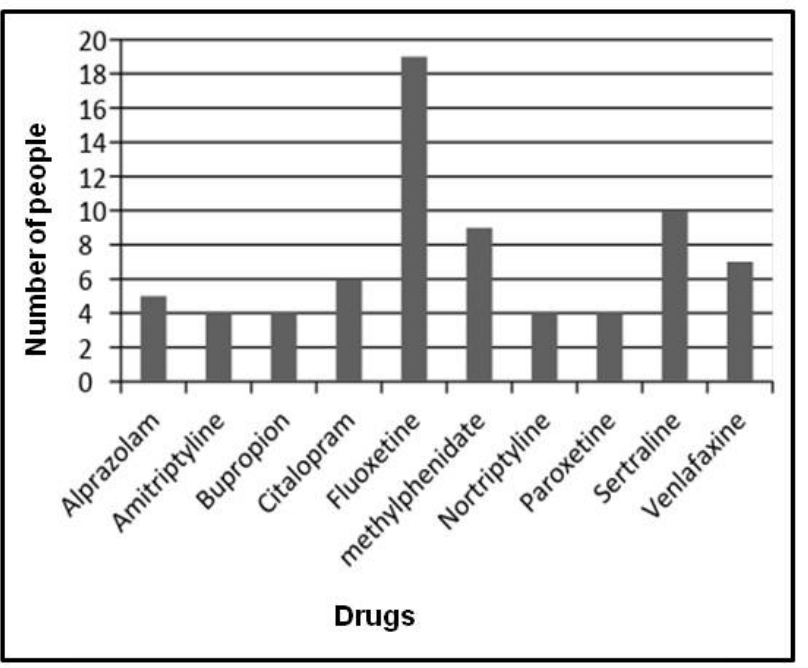

\section{DISCUSSION}

The results of the study show that there is a high prevalence of the use of psychoactive drugs by health science students, with a statistical association with faculty, semester, income, with whom they reside, and a positive family history of mental illness.

There was a higher prevalence of the use of psychiatric medication among females, although statistical significance was not found. Other studies provide information that gender seems to influence the mental health of medical students, with the female gender being a strong predictor of stress, anxiety, and depression ${ }^{9,18,19}$. Furthermore, stress in pharmacy students was associated with females ${ }^{20}$. 
Higher rates of the use of psychiatric medication were found among medicine and pharmacy students. A systematic literature review observed a high prevalence of stress and depression among medical students ${ }^{21}$. This can be influenced by a greater number of tests that these students go through during the program, and also because medical students are more competitive, self-critical, and socially isolated than students from other programs. High levels of stress during medical school can lead to the development of burnout syndrome, which is characterized by a state of physical and mental exhaustion connected to work or activities of care. Furthermore, studies have shown that medical students had a lower quality of life and had worse physical health associated with exhaustion and difficulty of sleeping, which can influence the use of medication ${ }^{22}$. In relation to the pharmacy program, some authors revealed the presence of exceptional levels of stress and anxiety in students, confirming that student life is generally stressful and anxiety-provoking for both genders ${ }^{20}$.

The semester of the program and the use of psychiatric drugs seem to be related since there was a stronger prevalence of use in the last period. Some authors have reported that Medical students during the final semester before graduation presented a high probability of using psychotropic drugs and an association between the most advanced academic year and symptoms of stress, anxiety, and depression $^{18}$. This could be explained by the proximity of the graduation, the completion of the program, and the preparation to make the commitment to practice the profession, in addition to preparing for medical residency exams at the time of specialization, when the selection processes are highly competitive ${ }^{23}$. Furthermore, it has been reported that pharmacy students present stress levels in the completion period of an academic degree. A cumulative effect throughout pharmacy school could be present in the last years of the curriculum, combined with higher demands probably due to the curriculum format of those years. Academic pressure, workload, and competition among colleagues may also explain the high levels of distress counterbalanced by personal traits and positive affective states ${ }^{20}$.

There was a trend to use psychotropic drugs when the income was higher. However, Wahed et al. ${ }^{22}$ have reported a significant association of lower socioeconomic class with depression and stress in Egyptian students. Furthermore, according to this research, students who grew up in poor families are more likely to develop depression or anxiety disorders and suicidal thoughts. The present study suggests the hypothesis that people with low financial status in Brasil would have greater difficulty accessing psychotropic drugs than people of families with good wages, but this was not confirmed.

The current study revealed that students living alone (living arrangement) showed significantly higher consumption of psychoactive drugs compared to students living with other people. Brenneisen Mayer et al. ${ }^{24}$ reported that housing accommodation could influence the quality of life of the students, and hypothesized that students who live alone have higher depression and anxiety scores. Other studies showed that living away from their families with a lack of social support are stressors and that family support systems could be a positive method of coping with stress for students living with parents or relatives ${ }^{19}$.

However, positive family history is a consistent indicator of depression. Individuals with a positive family history, even without high pre-onset stress, will have a longer period of depression in their life. Being especially vulnerable to mental illness, these people may require little provocation to start another episode of depression ${ }^{25}$. Panic disorder, generalized anxiety disorder, phobias, and obsessive-compulsive disorder (OCD) aggregate in families, according to Hettema et $\mathrm{al}^{26}$, the major source of risk being genetic. Thus, for some types of psychiatric disorders, genes largely explain this familial aggregation. Our study was in line with the observation that students with a family history of mental illness are more likely to use psychotropics compared to others without a family history.

Given that psychiatric medications are highly consumed, the study of their clinical safety is critical. Genotoxic studies, such as micronuclei assay of exfoliated epithelial cells from the buccal mucosa (BM), provide a measure of both chromosome breakage and chromosome loss and have shown strong potential as a tool for biomonitoring human populations exposed to genotoxic agents ${ }^{27}$. The advantages of the micronucleus assay of exfoliated oral mucosa cells are the statistical power obtained from scoring larger numbers of cells than the number typically used for metaphase analysis; the cells can be collected easily from the mouth in a minimally invasive manner; and the fact that the buccal mucosa is a highly regenerative tissue $\mathrm{e}^{14,27}$.

To the best of our knowledge, there is no study 
describing the genotoxicity of psychiatric medication using the micronucleus assay of exfoliated epithelial cells. However, other assays have been performed. Antidepressants such as Duloxetine (a potent inhibitor of serotonin and noradrenaline reuptake), Imipramine and Desipramine (tricyclic antidepressants) have had their genotoxic capacity previously demonstrated in in vivo assays in a mouse $\mathrm{e}^{28-30}$. The clastogenic, mutagenic and cytotoxic effects of trazodone (serotonergic antidepressant) and milnacipran (inhibitor of serotonin and noradrenaline reuptake) were investigated by using chromosomal aberrations (CAs), sister chromatid exchanges (SCEs), micronuclei (MN), and comet assays in cultured human peripheral lymphocytes ${ }^{31}$. El-Zein et al. ${ }^{32}$ analyzed CA, SCE, and MN frequency in peripheral blood lymphocytes obtained from twelve children treated for attention-deficit/hyperactivity disorder (ADHD) with therapeutic doses of methylphenidate. In all participants, treatment induced a significant increase in chromosome aberrations, sister chromatid exchanges, and micronuclei frequencies. However, results indicating that psychotropic drugs do not have a genotoxic potential were also described by other researchers ${ }^{33,34}$. Bozkurt et al. ${ }^{34}$ did not observe a statistically significant difference between SCE frequencies and CA tests in examined peripheral lymphocytes of sertraline-treated (administered orally at $50 \mathrm{mg}$ daily for 10 months to 1 year) and non-treated patient groups.

In the present study, the frequency of micronucleus and other nuclear abnormalities was not statistically significant between the case and control groups. However, there was an increase in the number of binucleated cells in the group exposed to psychotropic drugs.

Binucleated cells contain two main nuclei instead of one, which have the same morphology and staining intensity and are indicative of cytokinetic disturbance. Altered kinetics of cell division may be a response to environmental challenges ${ }^{35}$. Their formation is probably associated with aneuploidy, reflecting genomic instability ${ }^{14}$. In addition, Ilgreen ${ }^{36}$ has suggested that in many mammalian cell types the first step to higher ploidy levels is that the cells become binucleated, and these could play a role in the malignant transformation of a given cell population. The molecular mechanisms by which this induction is produced are far from understood. Possibilities such as malpositioning of the centrioles, the effect of drugs on the polymerization of tubulin, the disruption caused by the drug on microfilaments and microtubules, or even a possible effect on the polymerization of actin/myosin (responsible for the formation of the contractile ring during mitosis and/or cytokinesis have been described) ${ }^{37}$. Thus, our finding is relevant because of the implications in long term treatments with these drugs, taking into account that damage accumulation could have some significance for health status. The evaluation of the safety and benefit/risk ratio should be considered. Although there are several studies on the genotoxic effect of psychiatric medication, more information is needed and this deserves future investigation.

We acknowledge several limitations to this study. A longitudinal design would permit clarification of causal relationships and changes in students' psychological state, results that are not achieved with a cross-sectional study. Moreover, the sample size to study the micronucleus could be larger, although the groups of exposed students and non-exposed students were matched properly for several variables.

In conclusion, this study provides evidence that the use of psychoactive drugs, especially antidepressants, increases among health sciences undergraduate students, with associated risk factors including the program, the academic semester, the family income, with whom the individual resides and a family history of mental illness and that these drugs may be related to cellular alterations. These findings signal the relevance of consequent implementation of preventive programs to safeguard students' psychological state.

\section{ACKNOWLEDGMENTS}

The authors thank the students whose participation made this study possible and Global Science Editing Ltd for English editing services.

\section{FUNDING}

This study was supported by FAPESP (CBB - APQ01497-14), CNPq (441836/2014-3) and Universidade Federal de Ouro Preto (23109.003267/2017-01 and 23109.003268/2017-47).

\section{DECLARATION OF CONFLICTING INTERESTS}

The authors declared no potential conflicts of interest with respect to the research, authorship, and/ or publication of this article. 


\section{RESUMO}

O objetivo deste estudo foi avaliar a prevalência de uso médico e não médico de medicação psiquiátrica entre estudantes de graduação em Ciências da Saúde de uma universidade pública do Brasil. Outro objetivo foi determinar a frequência de anormalidades nucleares morfológicas na mucosa bucal desses estudantes. Realizou-se um estudo transversal baseado na Web com 375 estudantes de graduação em Ciências da Saúde das escolas de Farmácia, Educação Física, Nutrição e Medicina. Adicionalmente, danos genéticos espontâneos em células esfoliadas da mucosa bucal de 41 indivíduos foram analisados para estudo da frequência de micronúcleos e células binucleadas. Os resultados mostraram que 76 (20,8\%) dos estudantes relataram que usaram drogas psicotrópicas após se matricularem na universidade. O uso desses medicamentos foi maior entre estudantes de cursos de Farmácia e Medicina, sexo feminino, idade entre 18 e 25 anos, não tabagistas, alcoolistas e histórico familiar de doença mental. Além disso, estudantes de Medicina, indivíduos com alta renda, que moram sozinhos e estão no último período do curso são mais propensos a usar drogas psicotrópicas. Ademais, a exposição à medicação psiquiátrica foi capaz de aumentar o número de células binucleadas. Esses resultados fornecem evidências de que o uso de drogas psicotrópicas aumenta no contexto acadêmico e pode estar relacionado à falha do ciclo celular.

PALAVRAS-CHAVE: Aberração cromossômica. Utilização de drogas psicotrópicas. Estudantes.

\section{REFERENCES}

1. Mowbray CT, Megivern D, Mandiberg JM, Strauss S, Stein CH, Collins K, et al. Campus mental health services: recommendations for change. Am J Orthopsychiatry. 2006;76(2):226-37.

2. Blanco C, Okuda M, Wright C, Hasin DS, Grant BF, Liu SM, et al. Mental health of college students and their non-college-attending peers: results from the National Epidemiologic Study on Alcohol and Related Conditions. Arch Gen Psychiatry. 2008;65(12):1429-37.

3. Eisenberg D, Hunt J, Speer N. Mental health in American colleges and universities: variation across student subgroups and across campuses. J Nerv Ment Dis. 2013;201(1):60-7.

4. Martínez Gl, Martínez LM, Rodríguez MA, Mesa PA, Muñoz JE, Bedoya J. Características del consumo de fármacos psicotrópicos en estudiantes de ciencias de la salud. Vitae. 2008;15(2):244-50

5. Almeida AM, Godinho TM, Bitencourt AGV, Teles MS, Silva AS, Fonseca DC, et al. Common mental disorders among medical students. J Bras Psiquiatr. 2007;56(4):245-51.

6. Fiorotti KP, Rossoni RR, Borges LH, Miranda AE. Transtornos mentais comuns entre os estudantes do curso de medicina: prevalência e fatores associados. J Bras Psiquiatr. 2010;59(1):17-23.

7. Marchi KC, Bárbaro AM, Miasso Al, Tirapelli CR. Anxiety and the consumption of anxiolytics among nursing students of a public university. Rev Eletrônica Enferm. 2013;15(3):731-9.

8. Ribeiro AG, Cruz LP, Marchi KC, Tirapelli CR, Miasso Al. Antidepressants: use, adherence and awareness among medical students. Cienc Saude Colet. 2014;19(6):1825-33.

9. Ibrahim $M B$, Abdelreheem $M H$. Prevalence of anxiety and depression among medical and pharmaceutical students in Alexandria University. Alexandria J Med. 2015;51(2):167-73.

10. McCabe SE, West BT, Teter C), Boyd C). Trends in medical use, diversion, and nonmedical use of prescription medications among college students from 2003 to 2013: connecting the dots. Addict Behav. 2014;39(7):1176-82.

11. Wilens TE, Adler LA, Adams |, Sgambati S, Rotrosen |, Sawtelle R, et al. Misuse and diversion of stimulants prescribed for ADHD: a systematic review of the literature. J Am Acad Child Adolesc Psychiatry. 2008;47(1):2131.

12. Yuan A, Woo SB. Adverse drug events in the oral cavity. Oral Surg Oral Med Oral Pathol Oral Radiol. 2015;119(1):35-47.

13. Wright JM. Oral manifestations of drug reactions. Dent Clin North Am. 1984;28(3):529-43.

14. Thomas P, Holland N, Bolognesi C, Kirsch-Volders M, Bonassi S, Zeiger E, et al. Buccal micronucleus cytome assay. Nat Protoc. 2009;4(6):825-37.

15. Carrard VC, Costa CH, Ferreira LA, Lauxen IS, Rados PV. Micronucleus assay: a biomarker of genotoxic damage in exfoliated oral mucosa cells. R Fac Odontol Porto Alegre. 2007;48(1/3):77-81.

16. Carlini EA, Silva AAB, Noto AR, Fonseca AM, Carlini CM, Oliveira LG, et al. II Levantamento domiciliar sobre o uso de drogas psicotrópicas no Brasil: estudo envolvendo as 108 maiores cidades do país. São Paulo: CEBRID - Centro Brasileiro de Informação sobre Drogas Psicotrópicas: UNIFESP Universidade Federal de São Paulo; 2006. p.1-473.
17. National Institute on Alcohol Abuse and Alcoholism. Helping patients who drink too much: a clinician's guide. NIH Publication no. 05-3769. Bethesda: National Institute on Alcohol Abuse and Alcoholism; 2005.

18. Moutinho IL, Maddalena NC, Roland RK, Lucchetti AL, Tibiriçá SH, Ezequiel OD, et al. Depression, stress and anxiety in medical students: a cross-sectional comparison between students from different semesters. Rev Assoc Med Bras. 2017;63(1):21-8.

19. Fawzy M, Hamed SA. Prevalence of psychological stress, depression and anxiety among medical students in Egypt. Psychiatry Res. 2017;255:186-94.

20. Silva RG, Figueiredo-Braga M. Evaluation of the relationships among happiness, stress, anxiety, and depression in pharmacy students. Curr Pharm Teach Learn. 2018;10(7):903-10.

21. Ribeiro IJC, Pereira R, Freire IV, Oliveira BG, Casotti CA, Boery EN. Stress and quality of life among university students: a systematic literature review. Health Professions Education. 2017;4(2):70-7.

22. Wahed WYA, Hassan SK. Prevalence and associated factors of stress, anxiety and depression among medical Fayoum University students. Alexandria J Med. 2017;53(1):77-84.

23. Sarokhani D, Delpisheh A, Veisani Y, Sarokhani MT, Manesh RE, Sayehmiri K. Prevalence of depression among university students: a systematic review and meta-analysis study. Depress Res Treat. 2013;2013:373857.

24. Brenneisen Mayer F, Souza Santos I, Silveira PS, Itaqui Lopes MH, Souza AR, Campos EP, et al. Factors associated to depression and anxiety in medical students: a multicenter study. BMC Med Educ. 2016;16(1):282.

25. Monroe SM, Slavich GM, Gotlib IH. Life stress and family history for depression: the moderating role of past depressive episodes. I Psychiatr Res. 2014;49:90-5.

26. Hettema JM, Neale MC, Kendler KS. A review and meta-analysis of the genetic epidemiology of anxiety disorders. Am J Psychiatry. 2001;158(10):1568-78.

27. Faria LEM, Braga IRM. Aplicação do teste de micronúcleo para avaliação de potencial genotóxico em epitélio oral de estudantes universitários. Rev Eletrôn Atualiza Saúde. 2015;1(1):36-41.

28. Madrigal-Bujaidar E, Cárdenas García Y, Alvarez-González I. Chromosomal aberrations induced by imipramine and desipramine in mouse. Hum Exp Toxicol. 2010;29(4):297-302.

29. Paniagua-Pérez R, Madrigal-Bujaidar E, Reyes CS, Pérez G|, Velasco MO, Molina D. Sister chromatid exchanges produced by imipramine and desipramine in mouse bone marrow cells treated in vivo. Toxicol Lett. 2002;132(2):123-9.

30. Madrigal-Bujaidar E, Alvarez-González I, Madrigal-Santillán EO, Morales González |A. Evaluation of duloxetine as micronuclei inducer in an acute and a subchronic assay in mouse. Biol Pharm Bull. 2015;38(8):1245-9.

31. Avuloglu Yilmaz E, Unal F, Yuzbasioglu D. Evaluation of cytogenetic and DNA damage induced by the antidepressant drug-active ingredients, trazodone and milnacipran, in vitro. Drug Chem Toxicol. 2017;40(1):57-66. 
32. El-Zein RA, Abdel-Rahmanb SZ, Hayb MI, Lopez MS, Bondy ML, Morris $\mathrm{DL}$, et al. Cytogenetic effects in children treated with methylphenidate. Cancer Lett. 2005;230(2):284-91.

33. Pereira P, Gianesini J, Silva Barbosa C, Cassol GF, Von Borowski RG, Kahl VF, et al. Neurobehavioral and genotoxic parameters of duloxetine in mice using the inhibitory avoidance task and comet assay as experimental models. Pharmacol Res. 2009;59(1):57-61.

34. Bozkurt G, Abay E, Ates I, Karabogaz G, Ture M, Savran FO, et al. Clastogenicity of selective serotonin-reuptake inhibitors. Mutat Res. 2004;558(12):137-44.
35. Martins KF, Boschini Filho|. Determinação da frequência de micronúcleos e outras alterações nucleares em células da mucosa bucal de indivíduos não-fumantes e fumantes. Rev Fac Ciênc Méd Sorocaba. 2003;5(1):43-53.

36. Ilgren EB. The initiation and control of trophoblastic growth in the mouse: binucleation and polyploidy. Placenta. 1981;2(4):317-32.

37. Rodilla V. Origin and evolution of binucleated cells and binucleated cells with micronuclei in cisplatin-treated $\mathrm{CHO}$ cultures. Mutat Res. 1993;300(3-4):281-91. 